Original paper

\title{
Identification of Interruptions in Urban Drainage Systems and Their Sustainable Solutions for Alleviating Flood Risk in Mumbai, an Indian Megacity
}

\author{
Namrata Gaurkhede ${ }^{1^{*}}$, Vinayak S. Adane ${ }^{1}$ and Shraddha Khonde ${ }^{2}$
}

Received: 16/10/2020 / Accepted: 01/11/2021 / Published online: 10/12/2021

\begin{abstract}
Indian cities, in recent times, have been grappling with pressing natural disasters such as urban flooding and the dichotomy of acute water shortage. $24 \times 7$ water supply is a distant dream for the authorities involved. With an ever-increasing population leading to greater water demands, stormwater is increasingly considered an 'asset,' a resource that needs to be harvested. Mumbai, India's financial capital, being prone to chronic flooding, is a colossal problem for the country's economy. This review paper aims to identify direct and indirect interruptions in the stormwater drainage system of Mumbai, which in turn is leading to chronic flooding issues. This research identifies causative factors for flooding and observes that dilapidated and oldfashioned drainage systems are major hindrances in flood-free Mumbai. The traditional approach to urban infrastructure management needs to be reviewed and re-imagined. The identified interruptions in the drainage system were, thus, studied in detail to finally suggest some sustainable solutions, based on analysis and learnings from international success stories of cities having similar problems.
\end{abstract}

Keywords: Interruptions in Drainage, Mumbai, Flood, SuDS, sustainable

\section{INTRODUCTION}

Flood is the most frequently occurring disaster worldwide (EDMAT, 2019) and the biggest disaster in India, killing thousands in the last few years as per the National Institute of Disaster

\footnotetext{
${ }^{1}$ Visvesvaraya National Institute of Technology Nagpur

* Corresponding author email: namrata2707@gmail.com

${ }^{2}$ School of Planning and Architetcure, Bhopal
} 
Management (India). The intensity and frequency of these floods have been increasing steadily, resulting in amplified damage to life and the economy.

According to the IPCC, 2019, rare extreme flooding events may begin to occur annually. Some coastal areas are already seeing frequent higher sea levels during high tides and storm surges, thereby risking many low-lying cities and islands. Coastal migration and urbanization make flooding events even more damaging. The number of people living at low elevations is projected to increase threefold by 2100 . Without serious adaptation measures, flood risks may increase by 2 to 3 orders of magnitude. Rising sea levels threaten to erase coastal mega-cities such as Bangkok, Shanghai, and Mumbai (Climate Risk Index, 2020).

Coastal cities of Mumbai, Kolkata, Surat, and Chennai are under major threat. A total of 4 billion people will be hit by sea-level rise, melting ice, and glaciers (IPCC, 2018). Mumbai is the most vulnerable city regarding flood risks associated with anthropogenic activities (Dhiman et al., 2018). Mumbai currently ranks as the $5^{\text {th }}$ largest city (in terms of the population) globally (UNDESA, 2016). Mumbai has experienced several major extreme weather events within the past decade that have effectively brought the city to a standstill and caused severe human and economic losses (Shanghai Manual, 2010).

Mumbai is one of the most talked-about cities of India around the world when it comes to disaster and especially flood risks. Mumbai city is highly prone to disasters because of its natural hazard profile on account of factors such as - being a coastal city, having low-lying and hilly areas and seismicity of the landmass. The vulnerability is amplified due to human actions such as land reclamations, a high population density and encroachment of sensitive areas.

As stated by IPCC, 2019, if India continues to violate the Paris deal on low emissions, the water level will rise up to $100-110 \mathrm{cms}$, leaving no trace of Mumbai behind. There is an urgent need for a paradigm shift from 'response and relief' to 'prevention and mitigation' to make cities resilient (Dhankhar, 2017), and cities cannot simply pipe away flood risks. (Jainer, 2019)

This review paper aims to identify direct and indirect interruptions in the stormwater drainage system in Mumbai, leading to chronic flooding issues. Further on, it focuses on finding sustainable solution options to solve the issue in the complex urban setting of Mumbai.

\section{METHODOLOGY}

As part of this study, the authors looked at disasters in India, highlighting flood as the most occurring disaster in India and throughout the world and Mumbai as the most vulnerable city in the country.

Thus, detailed literature study was undertaken based on reports published by various government bodies and institutions on reasons for flooding in the city post the 2005 deluge. It also encompassed research published on the flooding issues in Mumbai, including national and 
international journals. It included studies related to the environment, climate change, governance, urban and infrastructure planning, engineering and implementation.

Reconnaissance surveys and interviews conducted in 2009 by the primary author (as a part of post-graduation studies from the School of Planning and Architecture, New Delhi) also form a part of the study.

The study focuses on the identification of causative factors for flooding in Mumbai. It was observed that all major problems related to flooding in the city could be categorized into six interruptions in the stormwater drainage system that have been leading to major flooding events in the city.

Additionally, based on a literature survey, the study touches briefly on some sustainable solutions for these six interruptions based on international success stories. The study concludes, stating the need to focus on the measures that need to be implemented to adopt a global sustainable urban drainage system locally.

Due to the scale of Mumbai city, the review paper is limited to highlighting the drainage issues leading to flooding and the sustainable solution options for them. These solution options have not been simulated or experimented upon in any part of the city.

\section{PROFILE OF MUMBAI, INDIA}

Mumbai is the commercial and financial capital of India and is also India's most populous city. The megacity had a population of 21.3 million (as per UNDESA in 2016). The municipal area of the city had a population of 13.8 million (as per Worldometer, United Nations 2020). It is located along the western coast of India and has the largest port in western India.

Mumbai was formed on two groups of islands, Heptanesia and Salsette islands. It has an average elevation of 10-15 meters above mean sea level. The coastline of the city is low-lying, with some points just one meter above mean sea level. Marquee zones such as the Bandra Kurla Complex (BKC), one of the most prominent commercial hubs with the highest property rates in the country; Worli, one of the most upscale areas; the International Airport of Mumbai are all low-lying areas. The original islands are at a higher level than the reclaimed areas.

The city is prone to multiple disaster risks, such as natural disasters like floods, landslides, cyclones, earthquakes, and manmade disasters like fire, industrial and chemical accidents, terrorist attacks, and riots. Mumbai had its biggest flood event in the year 2005, leading to the loss of hundreds of lives and a financial loss of US\$100 million. This flood covered $22 \%$ of the developed area of the city. As of today, around 10\% area of Mumbai is prone to chronic flooding. More than 55\% of the city's population, 11.9 million, live in slum areas and hutments (Jain, 2006). The in-migration has led to excessive urbanization visible in the population 
growth of $16 \%$ in the previous decade. The natural and manmade disasters, rapid urbanization, encroachments on disaster prone areas make Mumbai less resilient to any future disaster events.

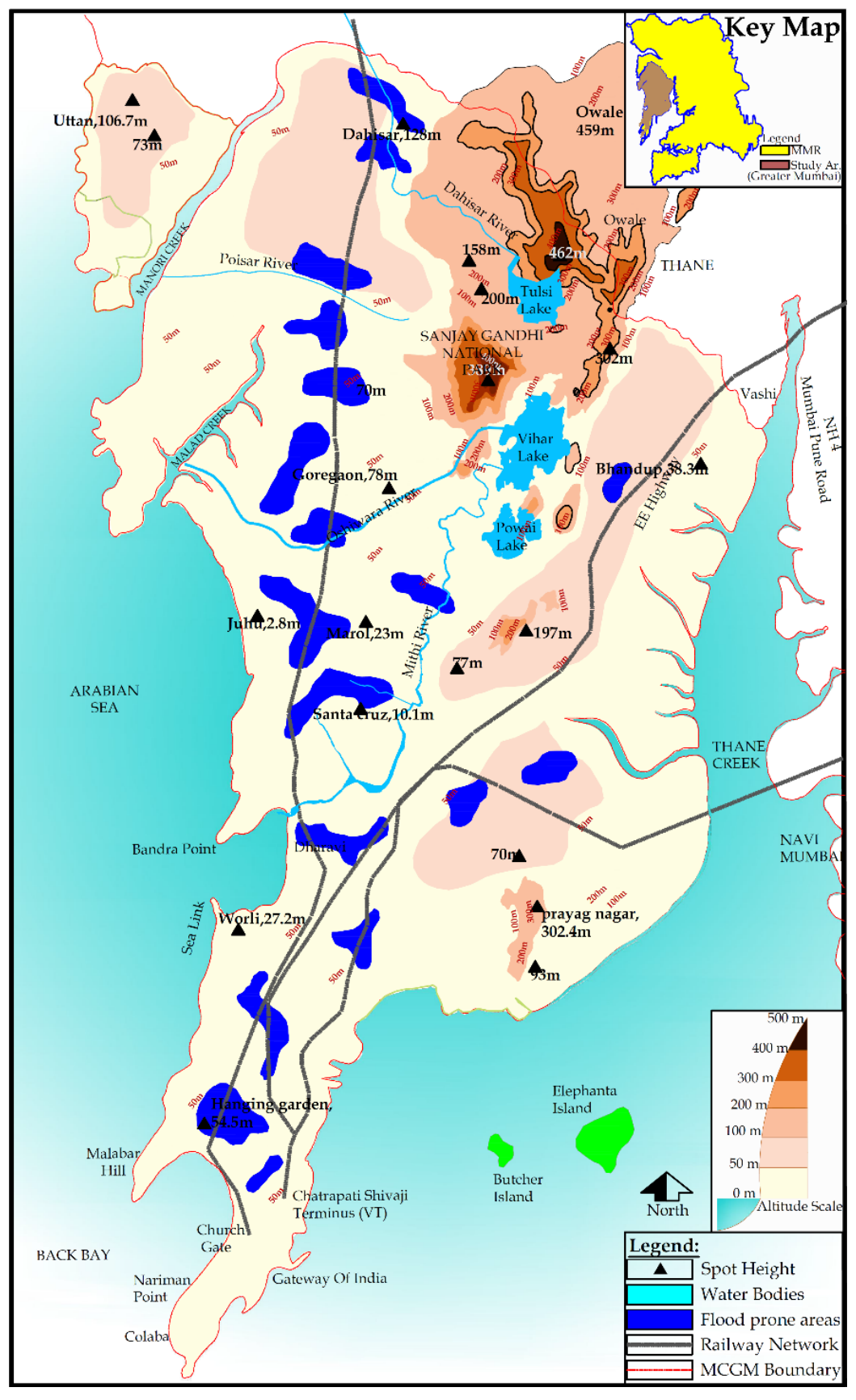

Figure 1. Landform, water bodies, and flood-prone areas, Greater Mumbai

Source: Drafted by the primary author based on GoogleEarth 2009, Toposheets and Mumbai an Estuary to a coastal city- SOAK, A Mathur and Da Cunha, 2009 (as a part of studies carried out in School of Planning and Architecture, New Delhi, in 2009)
The drainage system of Mumbai is a mix of simple drains and a complicated network of rivers, creeks, drains, and ponds. Mumbai is also served by five rivers which ultimately discharge into the Arabian Sea. (Bhattacharjee, 2018) A network of closed drains below the roads has evolved in the city whilst there are open drains in the suburbs (Gupta, 2009). According to Bhattacharjee 2018; the occurrence of high tides combined with heavy rainfall, constriction of natural waterways, the clogging of culverts, changes in the direction of natural stream flow, increased coefficients of rugosity due to crowding of structures, reduced hydraulic gradients due to silting, all gave rise to high flood levels and longer periods of inundation. The inadequate drainage system and ineffective spatial planning increase the flood risk in the region (Dhiman, et al., 2018). 


\section{REASONS FOR FLOODS IN MUMBAI}

There are several reasons for flooding. Thus engineers, researchers, and authorities have stated various reasons for flooding in Mumbai, especially after the $26^{\text {th }}$ July 2005 deluge. Some of them are listed in Table 1:

Table 1. Impact analysis of factors for flooding

\begin{tabular}{|c|c|c|}
\hline Causative factors for flooding & Reference & Result/Impact \\
\hline $\begin{array}{l}\text { Heavy rainfall, rainfall for longer } \\
\text { durations, sea-level rise, and tidal } \\
\text { variations }\end{array}$ & $\begin{array}{l}\text { Bobade } \text { et al., 2019; } \\
\text { Dhiman, 2018; Kadave } \\
\text { et al., 2016; Gupta, } \\
\text { 2007; CDP, 2006 }\end{array}$ & $\begin{array}{l}\text { Increased volume of stormwater to be } \\
\text { handled }\end{array}$ \\
\hline $\begin{array}{l}\text { Extensive land reclamation } \\
\text { activities, which were originally } \\
\text { low-lying areas, to accommodate } \\
\text { the growing population, } \\
\text { infrastructure development, } \\
\text { encroachments, etc. }\end{array}$ & $\begin{array}{l}\text { Bobade et al., 2019; } \\
\text { Dhiman, 2018; Kadave } \\
\text { et al., 2016; Gupta, } \\
\text { 2007; CDP, } 2006\end{array}$ & $\begin{array}{l}\text { The reclaimed area between the islands lies } \\
\text { below the high-water level obstructing the } \\
\text { outlet of natural water flow during rainfall } \\
\text { and causing water retention. }\end{array}$ \\
\hline $\begin{array}{l}\text { Improper development } \\
\text { regulations and lack of } \\
\text { enforcement of the plans, zoning } \\
\text { regulations leading to rapid } \\
\text { urbanization, encroachments on } \\
\text { hills, drains, water bodies, } \\
\text { mangroves, etc. }\end{array}$ & $\begin{array}{l}\text { Bobade et al., 2019; } \\
\text { Dhiman, 2018; Kadave } \\
\text { et al., 2016; Gupta, } \\
\text { 2007; Bhagat } \text { et al., } \\
\text { 2006; CDP, 2006 }\end{array}$ & $\begin{array}{l}\text { Loss of natural water holding areas; coming } \\
\text { up of dense areas in restricted zones, } \\
\text { increasing vulnerability; increased runoff } \\
\text { coefficient; hampered natural stormwater } \\
\text { drainage system; the increased load on city's } \\
\text { infrastructure }\end{array}$ \\
\hline $\begin{array}{l}\text { Dilapidated and faltering } \\
\text { drainage system with incapable } \\
\text { stormwater drains }\end{array}$ & $\begin{array}{l}\text { Bobade et al., 2019; } \\
\text { Dhiman, 2018; Kadave } \\
\text { et al., 2016; Jain, 2006; } \\
\text { CDP, 2006 }\end{array}$ & $\begin{array}{l}\text { Insufficient drainage cross-section to carry } \\
\text { floodwaters, leading to chronic waterlogging }\end{array}$ \\
\hline Encroachment on river basins & $\begin{array}{l}\text { Bobade et al., 2019; } \\
\text { Kadave et al., 2016; } \\
\text { Jain, 2006; Bhagat et } \\
\text { al., } 2006\end{array}$ & $\begin{array}{l}\text { Reduction in the catchment area of rivers } \\
\text { (reduced cross-section of the river), } \\
\text { hampering natural drainage system and } \\
\text { choking up the natural and manmade drains }\end{array}$ \\
\hline $\begin{array}{l}\text { Change in the path of the Mithi } \\
\text { River due to Airport runway }\end{array}$ & $\begin{array}{l}\text { Bobade } \text { et al., 2019; } \\
\text { Kadave et al., 2016; }\end{array}$ & $\begin{array}{l}\text { Disturbance in the natural watercourse } \\
\text { resulted in increased rainfall run-off }\end{array}$ \\
\hline $\begin{array}{l}\text { Construction on the mouth of } \\
\text { river basins }\end{array}$ & $\begin{array}{l}\text { Bobade et al., 2019; } \\
\text { Kadave } \text { et al., 2016; } \\
\text { Jain, 2006; }\end{array}$ & $\begin{array}{l}\text { Led to creation of bottle-necks during heavy } \\
\text { rains which in turn resulted in reduction in } \\
\text { outfall }\end{array}$ \\
\hline $\begin{array}{l}\text { Combined sewage and } \\
\text { stormwater drainage system }\end{array}$ & $\begin{array}{l}\text { Bobade et al., 2019; } \\
\text { CDP, } 2006\end{array}$ & $\begin{array}{l}\text { Choking of drains due to sullage/ sewage } \\
\text { inflows } \\
\text { Obstruction due to crossing of utility lines }\end{array}$ \\
\hline Poor maintenance of drains & $\begin{array}{l}\text { Bobade et al., 2019; } \\
\text { Bhagat et al., 2006; } \\
\text { CDP, } 2006\end{array}$ & $\begin{array}{l}\text { Encroachments on drains \& enhanced silting, } \\
\text { reducing water retention capacity of natural } \\
\text { water bodies }\end{array}$ \\
\hline $\begin{array}{l}\text { Garbage dumping in drains by } \\
\text { irresponsible citizens }\end{array}$ & Bhagat et al., 2006 & $\begin{array}{l}\text { Choking of drains, obstructing the water flow } \\
\text { during rains }\end{array}$ \\
\hline $\begin{array}{l}\text { Administrative responsibility } \\
\text { and Governance }\end{array}$ & Bhagat et al., 2006 & $\begin{array}{l}\text { Multiple administrative and development } \\
\text { agencies leading to uncontrolled and } \\
\text { unplanned development }\end{array}$ \\
\hline
\end{tabular}


Thus, the major causative factors of flooding include extensive land reclamation, developments on river basins, heavy rainfall combined with poor design of drainage system, poor maintenance of infrastructure and increased runoff coefficient. These factors act as interruptions in natural and manmade stormwater drainage system. The identified factors need to be appraised at length to establish the hindrances in stormwater flow and discharge, leading to flooding situations.

\section{INTERRUPTIONS IN STORMWATER DRAINAGE OF MUMBAI}

These causative factors affecting the drainage system have been combined to investigate their further implications in flooding.

\subsection{Land Reclamation}

The entire city of Mumbai is geographically admeasuring about 440 sq. km. as per the latest Draft Development Plan 2014, landfills are developed between the seven islands North to South (Arunachalam B., 2005). Once separated by swampy areas, the seven islands were joined over 150 years, starting in the $16^{\text {th }}$ century. The reclamations began to accommodate the increasing population in the fort area. Thereafter, several reclamations were carried out to connect various parcels of land till 1845. The Island city has $32 \mathrm{sq} . \mathrm{km}$ of reclaimed area (Fact Finding Committee, Mumbai 2006), whereas the total reclaimed area in Mumbai is 96 sq. km. Reclamations also took place due to dumping of household waste and industrial waste, wanton quarrying, etc. (Indian Institute of Technology-Bombay, 2014). The central area comprises mainly the low-lying reclaimed area. (Bhattacharjee, 2018)

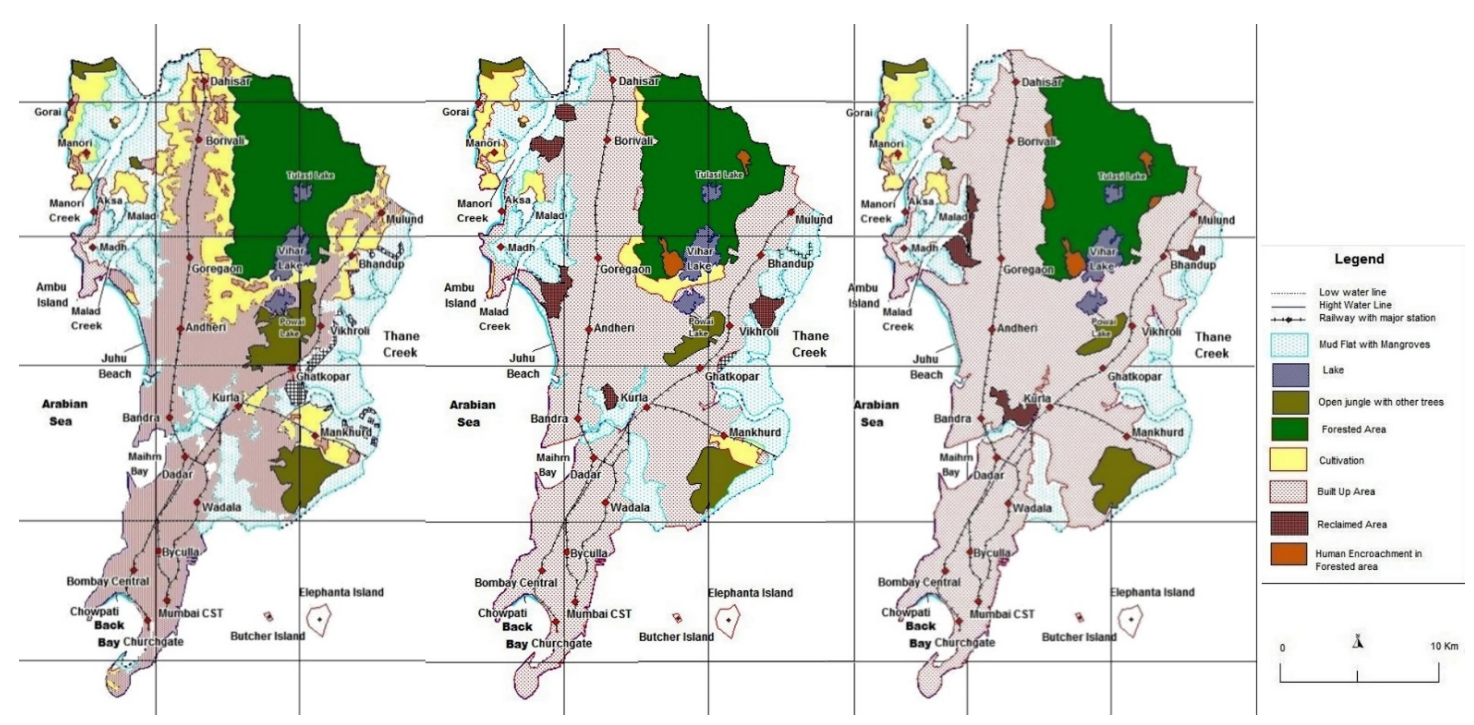

Figure 2. Change in landuse and increased development on reclaimed land Source: Mumbai Technical Support Unit report, 2015 

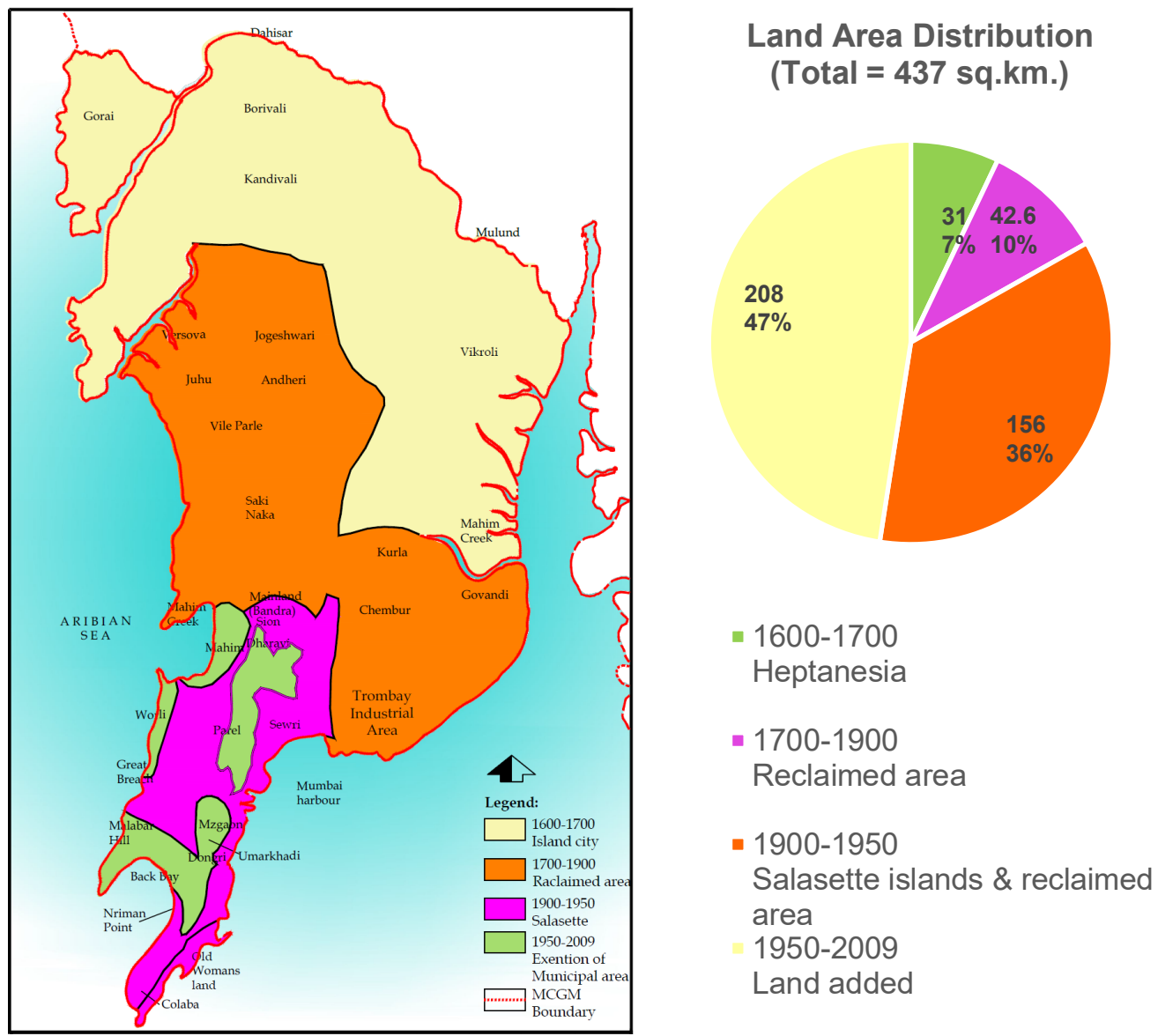

Figure 3. Land Reclamation of Greater Mumbai 1600-2009

Source: Drafted by the first author (as a part of studies carried out in School of Planning and Architecture, New Delhi, in 2009) 2009 (Based on City Development Plan (of Mumbai) 2005-25)

Even in the $20^{\text {th }}$ century, Mumbai continued to develop on reclaimed lands. Land reclamation decreased swampy areas and increased concretization, thus reducing the infiltration of rainwater. Concretization also reduced the width of the creeks and estuaries, increasing inundation and waterlogging in every season. The flood-prone areas are currently constantly under a chronic threat of disaster risk. Reclaiming land from the sea has led to changes in the coastline regime, loss of mangroves, upstream flooding of rivers, changes in an undercurrent and tidal wave patterns.

Over $40 \%$ of it is reclaimed land from the sea by filling in inland lagoons and marginal seas, just at or above sea level and almost one-fourth of land lies below mean sea level. (Arunachalam B., 2005). Around $22 \%$ of the reclaimed area is flood-prone (calculated by author 1 in School of Planning and Architecture, New Delhi in, 2009) as unplanned and unscientific reclamation methods were adopted. These reclamations are in complete violation of the Coastal Regulation Zones. The latest petition filed in the Bombay High Court case, The Conservation Action Trust And supporters ... vs Union of India And 3 Ors on 16 July 2019 has 
a complete detail of all the violations from time to time. (Bombay High Court, 2019 https://indiankanoon.org/doc/137208673/?type=print)

\subsection{Developments on River Basins}

Mumbai has rivers Mithi, Dahisar, Poisar, Mahul, and Oshiwara which discharge directly into the Arabian Sea. Mithi river acts as the major component for natural drainage, running across the city with a catchment of approximately $108 \mathrm{sq} . \mathrm{km}$. The river originates in the overflowing water from lakes Tulsi, Vihar, and Powai (in the North), from the ridges, valleys of Borivali hills, and the spot where (prior to development) the current L\&T factory stands in Powai.

According to a study conducted by Samant H.P. in 1996, an area of over 156 sq. km acted as drainage basins for majority of the streams which discharge into the main creeks of Mumbai. These basins have now been built upon with roads, buildings and slums. This construction is particularly found along the Mithi River and in the Jogeshwari to Kandivli zone. During recent decades, the indiscriminate and unprecedented growth of Mumbai has created ecological hazards and ignored the countryside, which has been turned into a weak margin. (Jain, 2006). Figure 4 shows the reduction in basin area since 1740, and the year 2014 map shows the extent of reclamation which has sealed one end of the Mahim estuary.
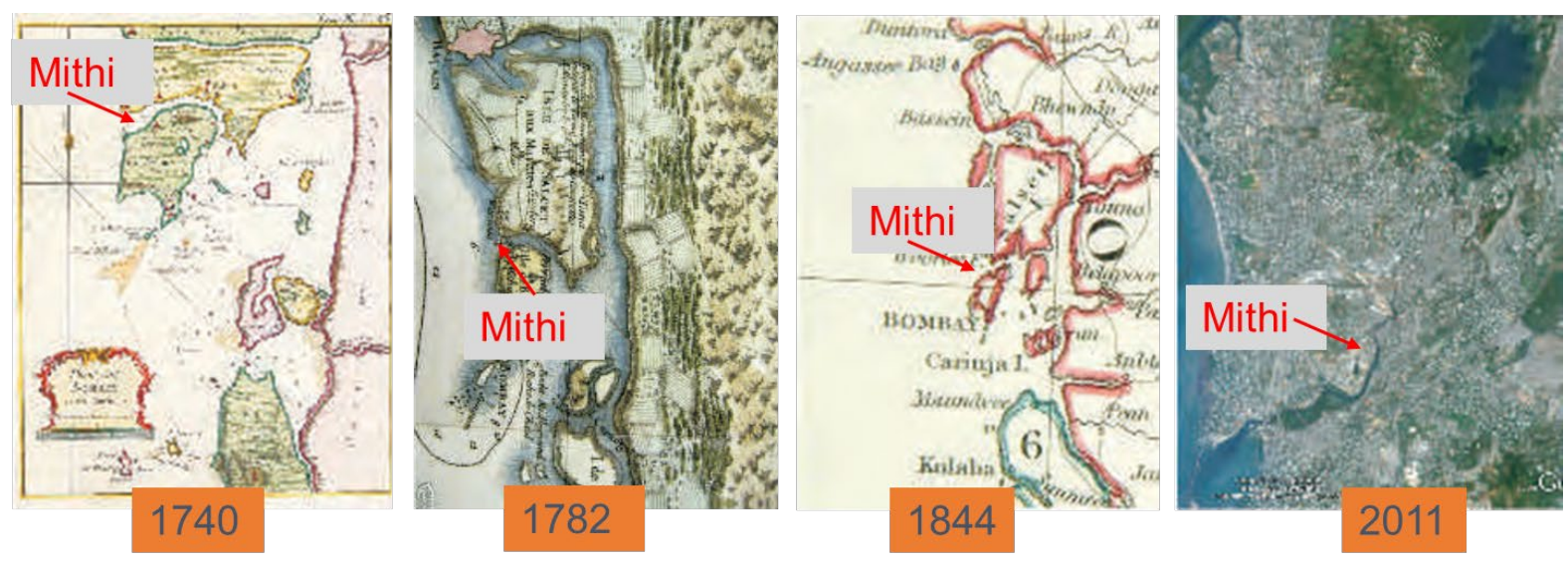

Figure 4. The Mithi River and the Mahim Estuary

Source: Kirtane G., 2011

Many large-scale planned developments and encroachments on the Mithi river basin have changed the area's topography. The new sea link has reclaimed the river mouth by about 0.27 sq. km of landfill (Gupta, 2009). The expansion of the International Airport resulted in the Mithi river being passed through a tunnel below the runway. The river was first bifurcated during the construction phase and then reunited, forming a small island which was then utilized for airport extension (Kirtane, 2011). Mudflats acted as holding ponds during 1992-2009 with Bandra Kurla Complex (BKC). The Mithi River in the North reduced to an open drain due to 
severe encroachments and the discharge of industrial effluents into the river. Nearly $54 \%$ of the original river flow has been lost to slums, roads, and new developments (Census of India, 2001). Most of the flooding hotspots identified by the municipality lie in the Mithi river basin, which includes Rajiv Gandhi Nagar (a slum in Dharavi), Kothu Wadi (slum and low-income group), Kalina Market, Prem Nagar(slum), and Parsi Chawl(slum). These slum areas are densely packed, increasing the vulnerability.
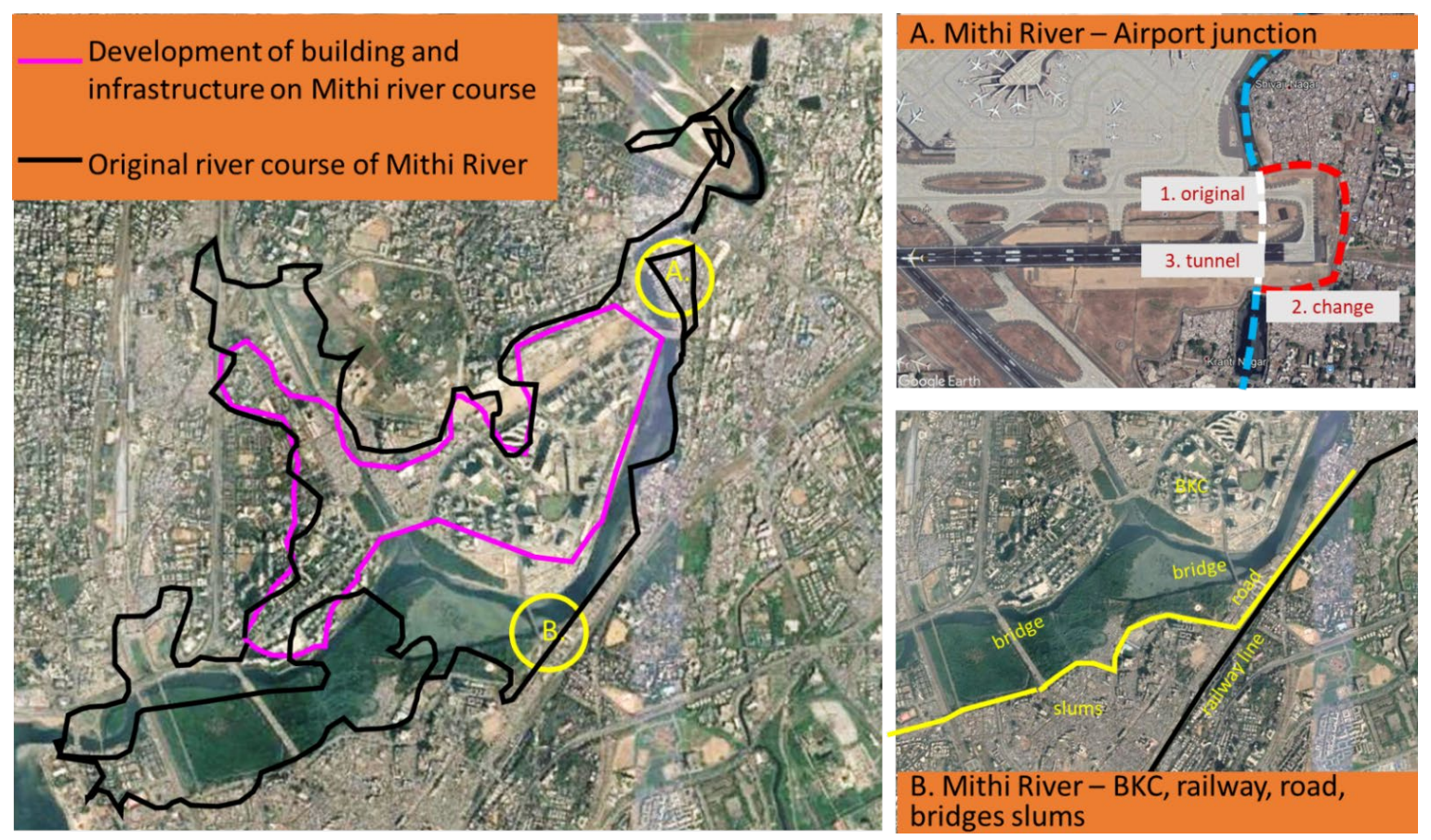

Figure 5. Change in the course of Mithi River (1966-2009), Mumbai

Source: Recreated by authors on 2021GoogleMaps (Primary source: Zope et al., 2012)

Other rivers in the northern suburbs which overflowed (during the 2005 floods) are the River Dahisar and the River Poisar (Gupta, 2009). These encroachments act as blockage to rainwater running towards the river. Development (even with permission from the municipality) without proper environmental clearance increases the pressure on the existing drainage system, which is already poor and old fashioned. Mangrove areas along the rivers have been diminished and destroyed, disturbing the natural ecosystems and increasing flood risk. As the planning authorities have permitted construction on floodplains, the consequences of encroachments in the Mumbai area seem to be far worse.

\subsection{Design and Capacity of Drainage Systems}

The city is a combination of natural and manmade drainage systems. Topographically, the city area is a linear central bowl or depression, with low lines of hills on either side. The rain water naturally gravitates and drains into the central depression. (Arunachalam, 2005) This 
central depression, barely 2-3 meters above mean sea level, is liable to flooding and drained by several rivers, like Mithi, Poisar, Dahisar, and others (Mallad \& Mahim Creeks. There is a drastic increase in the pressure on the drainage infrastructure due to change in rainfall patterns, reduction in pervious land area, increased surface run-off, additional sewage load in the combined sewer system and dumping of waste in the drains.

The current piped drainage system of Mumbai is 80 -year-old, with about $480 \mathrm{~km}$. of underground drains and laterals, and designed to handle a rainfall intensity of $25 \mathrm{~mm}$ per hour at low tide with a runoff coefficient of 0.5 . The city has 186 natural and manmade outfalls, only 45 of which discharge below the mean sea level, and only three outfalls have floodgates. The rest open directly into the sea. After the 2005 Mumbai floods, an upgraded drainage system was proposed and millions of rupees were sanctioned for the same but it is yet to be implemented.

The stormwater drainage in Mumbai is combined with the sewage system. Only $60 \%$ of the city area is covered with a sewage system with the waste being disposed in the Thane creek, Colaba harbor, Arabian Sea, and Malad creek. Sewage system remains absent in the remaining $40 \%$ of the city area leading to unattended and unmanaged sewage polluting the seawater. The Maharashtra Pollution Control Board has identified 70 drains that discharge untreated sewage into the waterbodies. The current sewer lines are over-burdened, owing to the high rate of urbanization, pressurizing the already under-designed, overburdened rainwater system. Open defecation is still being practiced due to the lack of toilet facilities in slums, ultimately contaminating water bodies.

According to Arunachalam B., 2005, a future problem not yet realised in terms of gravity is that mains of the underground sewerage are old and obsolete, over 100 years old, and with leaks in many places, often mingling with drinking water pipes running close to the sewerage lines. Since stormwater and sewage outfall into the sea, tidal variation has a major bearing on the drainage system resulting in water logging during heavy rains. Interconnection of sewage and stormwater network is leading to siltation and loss of drainage capacity. (Bhattacharjee, 2018) The earlier the sewage drainage and stormwater drainage are segregated, the cleaner the city environment. (Arunachalam, 2005)

\subsection{Maintenance of Drainage}

The problem of dilapidated, old-fashioned sewage and drainage system is amplified with their maintenance issues. Clogging due to dumping of waste in open drains/nullahs/water bodies, ultimately blocking the connected underground piped drainage. Also, slums along the rivers, for example, Dharavi, are discharging their wastewater directly into the rivers through open nullahs. The total width of the walkway between two houses in the Rajiv Gandhi slum, Dharavi, is three feet, out of which one foot in the center is being used for carrying stormwater and wastewater (illustrated in figure 6). 


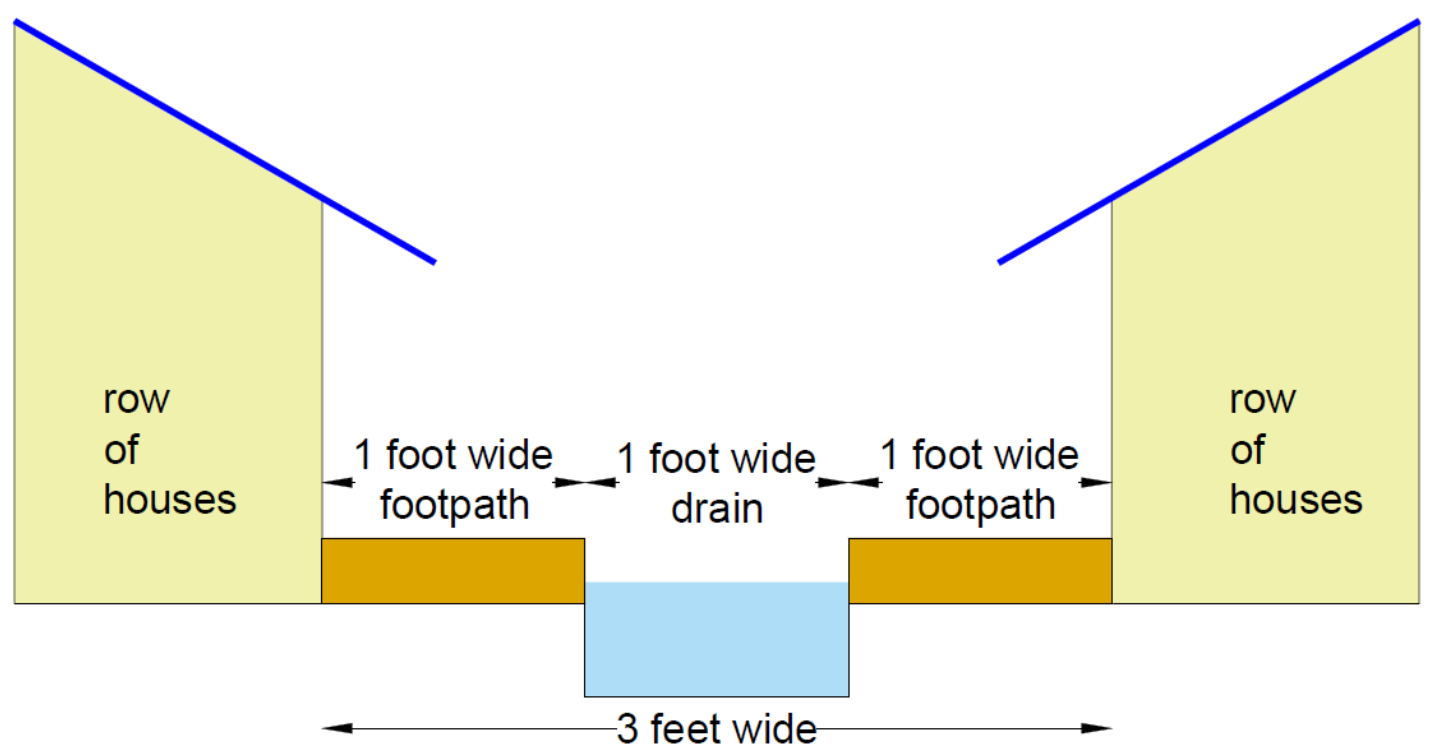

Figure 6. Depiction of the pathway with a drain in Rajiv Gandhi Slum of Dharavi, Mumbai

Source: Illustrated by the author as per site visit

Another issue obstructing the flow in drainage infrastructure is street vendors, shops, etc., illegally covering the drains at many points. The drainage system has been historically plagued by poor workmanship in construction, lack of attention to proper repairs, and accumulation of waste, especially where the drains have been punctured. As already discussed, the interconnection of stormwater \& sewerage networks adds to the maintenance pressure of these drains. Brihanmumbai Municipal Corporation (BMC), in charge of maintaining and upgrading city infrastructure, has produced reports stating the needed road and drainage upgrades throughout Mumbai. (Stecko, 2007) At some locations, there are makeshift crossover bridges/bunds by the citizens on rivers, hindering the natural flows.

The freshwater pipeline passes just above these soiled rivers at several locations, leading to additional problems during flood events, polluting the potable water line, causing epidemics, and adding to the after-effects of the disaster. Chatterjee, 2005 has highlighted an institutional issue that many municipalities in India today outsource the actual de-silting of drains. Typically, the waste that is cleared out is kept alongside the drains because it would add to the costs to transport them long distances. When it rains heavily, all that waste goes back into the drains through gutters.

Several drives at municipality, community and NGO levels to desilt the drains are being carried out. The issue can be resolved when all the above maintenance aspects are taken up immediately. Institutional arrangements and funds to manage infrastructure needs are also lacking. 


\subsection{Reduction in mangrove areas}

Mangroves act as a sponge in floods in an area by absorbing volumes of the excess water. In Mumbai, mangrove ecosystems along the Mithi River and Mahim Creek are being destroyed by construction activity. Mangroves had shrunk by $32 \%$ from an area of $235 \mathrm{sq}$. $\mathrm{km}$ in Mumbai in 1924 to only 160 sq. $\mathrm{km}$ in 1994. An additional ten sq. $\mathrm{km}$ of mangroves are estimated to have been destroyed in Mumbai by 2000 (Jain, 2006). A total loss of 40\% till 2005, some to public infrastructure, some to builders and some to encroachment (slums) can be logged in.

One of the major developments that have taken over the mangroves is the Bandra Kurla Complex (BKC) which came up on 3 sq. km of mangrove land. The Environment Ministry of the Government of India had informed the local bodies about its (construction of BKC's) potential disaster and had appealed not to sanction it but no action was taken on time. Similarly, the basins in the western suburbs that flow into the Malad creek have been built upon without accommodating the natural drainage pattern; thus, the overflow has flooded the nearby areas. (Jain, 2006). Earlier, the Mithi River, along the expressway in Ghatkopar area used to flow freely. It has now been reduced to a narrow drain (Jain, 2006). Other major developments on mangrove and mudflats include the solid waste dumping yards, Essel world (theme park), major residential societies and many more.

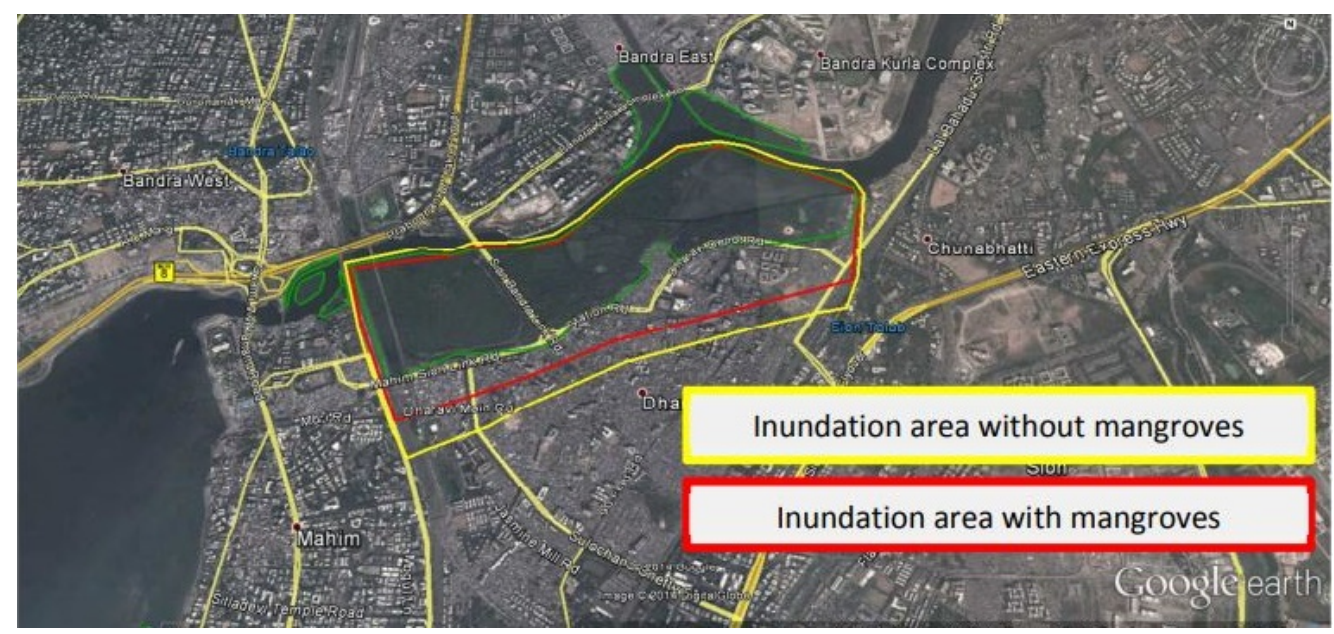

Figure 7. Flood inundation map of mangrove forest on Mithi river basin Source: Khan, M. 2014

Another factor that hampers the effective functioning of mangroves is the dumping of garbage, industrial effluents, and untreated sewage. This issue is amplified during flood events, where rainwater carries along with waste from the city into these mangroves. These pollutants prevent seawater from entering the mangroves, eventually killing them.

According to a simulation carried out by Khan, 2014 along Mithi River, the presence of mangroves reduces the flood-affected area by $21 \%$, as indicated in Figure 7 , confirming the 
significance of mangroves at the river bank. There is an urgent case to protect the remaining mangroves, creeks, and green areas and to restore the original drainage basins, water channels, and culverts in the reclaimed areas. Ecological factors should be the basis of future planning and development of Greater Mumbai (and any other Indian city) to avoid future catastrophes. (Jain, 2006)

\subsection{Increased runoff coefficient}

The migration of people from rural to the urban area has led to rapid LULC (land use-land cover) changes to satisfy the population's needs. Thus, there is tremendous growth in urban areas in developing countries all over the world. Being an island city, Mumbai faces a scarcity of land and has limitations for horizontal development (Zope et al. 2016). Urbanization reduces the land porosity of an area that absorbs rain waters. Otherwise, it runs off into the already overloaded drainage system, including piped drains, rivers, streams, canals. Impermeable surfaces, sea-level rise, and river discharge threaten $15 \%$ of the world's population (Sörensen et al. 2016).

The built-up area has increased due to construction of buildings, concretization and macadamisation of roads. This combined with the release of more sewage from the increasing population in buildings and hutments - all add to the gravity of the situation. This is the reason why waterlogging continues for days together in the central depression (of Mumbai) (Arunachalam, 2005). Storm Water Drainage capacity inadequacies are due to an increase in the overall runoff coefficient due to loss of holding ponds and encroachments alongside drains, disturbing catchments runoff (CDP Mumbai, 2005-25, 2006). According to a study conducted by the School of Planning and Architecture, New Delhi (SPA 2009), since 1994-2009, over 1000 plots of public land have been released for construction; $50 \%$ of the city's no-development zones have been built upon. The local development authorities have given these permissions. The slum areas are always called as encroachment, but these so-called authorized constructions are now encroaching upon the natural systems existing in Mumbai, which equally are responsible for the chronic flooding in the city.

Another issue is that most detention ponds have been lost to development, and it is estimated that urbanisation has contributed to increased runoff by 2-3 times (Gupta, 2009). The progressive reduction of open lands has substantially reduced the natural percolation areas of water into the ground and thus contribute to the stormwater collecting on the surface. (Arunachalam B., 2005)

As per Figure 8, between 1981 to 2001, increased mixed, residential, and commercial land use led to the shrinkage of wetlands (around 10\%). Also, the built-up area has doubled during 1971-2001 to 52\%, reducing the forest/vegetation cover, mangroves, etc. It needs to be noted that increase in built density of the urban areas is at the expense of cultivated lands, forests, and water bodies. (Applied Geography, Indian Institute of Technology-Bombay, 2019). 


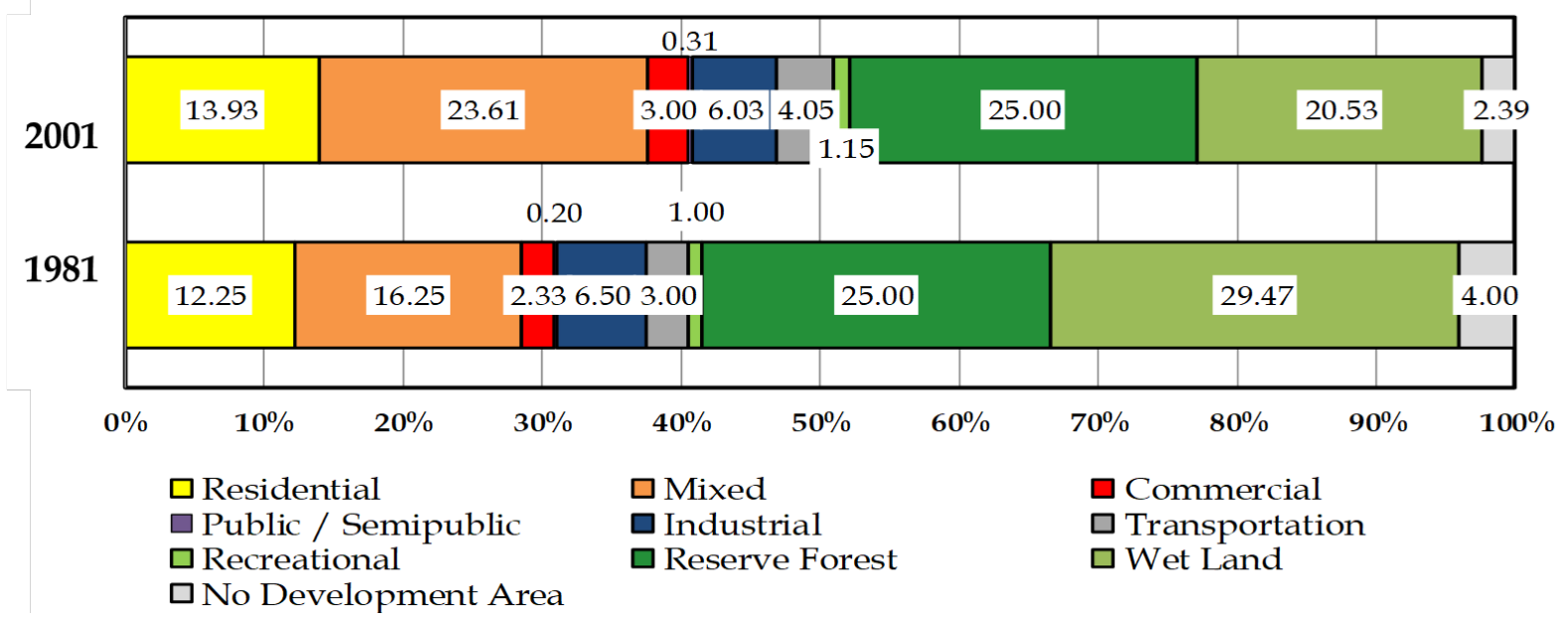

Figure 8. Landuse distribution, Mumbai

Source: Mumbai City Development Plan 2005-25

The streams and rivers have been concretized and bund walls have been constructed as flood defense measures. However, this has reduced porosity of the streams. It is considered that runoff coefficient for paved surfaces is 0.95 (Mr. Haestad's International Standard Handbook), which means that more than $50 \%$ of the city's area is non-porous, resulting in floods in heavy rainfall. There is an intrinsic relationship among drainage, landuse planning, and ecology, which should be organized and coordinated so that the demands of the growing population, housing, drainage, and water supply are met without comprising the ecology. (Jain, 2006)

In another study conducted by Zope et al. 2016, the impacts of LULC and urbanization on flooding have been investigated for a Mumbai catchment of Oshiwara River over 43 years. It showed a $74.84 \%$ increase in the built-up area and $42.79 \%$ and $62 \%$ reduction in open spaces and water bodies respectively.

\section{DISCUSSION}

After the 2005 deluge, the Municipal Corporation of Greater Mumbai came up with an upgraded drainage system design. They have now considered the run off as $100 \%$, considering the hydrological pattern. The rainfall intensity is considered $50 \mathrm{~mm}$ per hour with runoff coefficient as 1 in place of earlier design intensity of $25 \mathrm{~mm}$ per hour with a runoff coefficient of 0.5. Bobade et al., 2019 have suggested an underground piped drainage system (conventional) stormwater drainage system for Mumbai. Contrary to that, Jain, 2006 has insisted on having a bio-drainage system not just for Mumbai but also for India. Also, Kadave et al., 2016 have suggested combining the conventional and modern solutions to flooding with solutions like cleaning of Mithi River, bores, percolation tanks, planting and preserving mangroves along with new stormwater drains. Alternative ways to manage floods have 
evolved since traditional methods often harm the riverine ecosystems in urban and rural areas and increase the long-term flood risks. Sörensen et al., 2016

Studies establish that $90 \%$ of Mumbai's storm drainage is through storm drains, and only $10 \%$ is through open lands. This leads to additional challenges and load on an outdated and under capacity storm water drainage infrastructure that is more than 100 years old (Rawoot et al., 2015). It can be observed that the interruptions in the drainage system mentioned above are not limited to the issue of the design capacity of the drainage system. It calls for an integrated water management solution to handle flood issues in Mumbai.

Indian cities frequently face flooding caused by poor drainage, and a severe shortage of water, especially before the monsoons. This is largely a consequence of the adoption of borrowed concepts of urban drainage, together with indiscriminate and unplanned developments in the natural drainage channels (Jain, 2006). The CPHEEO Manual (India), 2019 cites that stormwater is now increasingly being valued as a resource to address water security in urban areas. According to Chan et al., 2018, sponge city can achieve the dual goals of sustainable water use and better flood control. It is influential and revolutionary in its approach to land-use planning; urban water-resource management, urban flood, and climate risk mitigation; ecological enhancement; and social wellbeing. Also, according to Sieker, 2009, there is need for a paradigm shift from conventional drainage approach to a modern approach - from "Getting rid of stormwater as quick as possible" to "Maintaining natural water balance". As per Das, 2012, implementation of the principles of SuDS can help tackle the threat posed by the mismanagement of urban stormwater runoff and regenerate fast depleting groundwater aquifers.

The sustainable urban drainage system (SuDS) aims to mimic natural hydrological processes in an area/ city which is altered due to urbanization. SuDS creates sponge areas and provides an opportunity to capture and treat runoff by intercepting, filtering and degrading pollutants and reducing potentially contaminated runoff volume (CIRIA, 2015). Some of the advantages of SuDS include increased water quantity, improved water quality by preventing pollution, the addition of amenity areas, and increased biodiversity through the introduction of new ecosystems. Over the years, several countries have adopted various versions of SuDS, including the US, UK, New Zealand, China, France, Japan, Singapore, Australia, Netherlands, Denmark, Sweden, Germany, South Africa, and many more. While it was earlier focused only on flood management, its scope has been increasing over the years, with multiple benefits being realized.

\section{SUMMARY OF INTERRUPTIONS AND THEIR SUSTAINABLE SOLUTION OPTIONS}

In the absence of a systematic and sufficient drainage system, the city of Mumbai has been facing flood issues for decades. Although it is time to revive the city's natural drainage system, 
implementing sustainable solutions can be challenging considering the scale of the megacity. As per international success stories, the application of sustainable drainage solutions but based on localized climatic factors, land constraints, Governance, and public response must be taken up as pilot projects initially. The following summary includes likely sustainable solutions for reducing flood issues in the city, with international examples of context similar to Mumbai city.

Firstly, the land reclamations that have already been taken up in the city are major areas of depression. Identification of reclaimed parcels of land which have not been taken up for development and re-creation of marshy/ swampy areas, along the water bodies (lakes, streams, rivers, sea) may be taken up at all possible locations. For example, removal of Deonar landfill area in east Mumbai; creating wetlands at multiple unused locations inside the Essel World Amusement Park. In the Wallasea Island Wild Coast project, UK, a wetland landscape of mudflats and salt marshes, lagoons and pasture was installed for the coastal defense of an originally reclaimed island. The project's environmental benefits included habitat creation, waterborne nutrient processing, and the provision of fish feedings and nursery habitats. In addition, the society at large benefitted from avoided expenditures for flood defence infrastructure and the avoided loss of built assets on Wallasea worth millions. (Davis et al., 2016). Concurrently, the local government must put an immediate end to "authorized" reclamation, and strict checks must be kept on "unauthorized" reclamation (by the ULBs).

Secondly, the encroachments on river basins and buffer zones of water bodies causing hindrance in functioning of the natural drainage system require urgent attention. The local bodies may have to clear the authorized and unauthorized encroachments with planned relocation of developments. For example, the long due redevelopment of slums along Mithi river basin while leaving buffer for the river can be taken up. After this, restoration of all water bodies with urban local bodies, non-profit organizations, citizens can be taken up. Also, all future plans of development on river basins in Mumbai by the local bodies will have to be stopped and a strict check on unauthorized development should be kept. According to an onground research and testing carried out by Boogaard, 2015 in the Netherlands, it was demonstrated that most of the bioretention swales and permeable pavements tested met the required hydraulic performance levels even after years in operation and without maintenance. Bioswales, which have been successful in several countries, can be created in the buffer areas of water bodies, limiting the dumping of waste in them. The rivers need to be made pervious again by de-concretizing them. This task can be taken up in phases, along with developing the water bodies for public use.

Another major issue that came to the fore is the mixing of sewage with stormwater leading to increased load on the drainage system and polluting the water bodies at outfalls. While it is challenging to do so, it may be required to disconnect storm water drainage from sewage drains in phases and set up treatment plants with advanced and natural treatment methods and disposal of sewage. A study was carried out by Perales-Momparler et al., 2013 wherein some inner-city sites in the Mediterranean region were retrofitted with SuDS components to promote sustainable stormwater management. Scenario building with climate and SuDS options 
confirmed that the existing combined sewer networks were insufficient to manage the runoff appropriately, leading to floods in several networks.

The absence of a sewerage system (connections, conveyance, treatment, and disposal) in a major portion of the city pollutes the water bodies, and an open / semi-open stormwater drainage system is a pressing situation. Immediate planning and provision for sewerage connection in the areas where it is absent may have to be carried out for the success of existing and future drainage solutions. Smaller sewage treatment zones can be created to treat the waste close to the source and reuse some part of treated water before discharging it into the water bodies. This can be implemented in the large slum pockets as the slum population constitutes around $55 \%$ of the population, which lacks this infrastructure. This will reduce the burden on the already overloaded drainage and sewage system.

Insufficient, dilapidated and over-burdened natural and manmade drainage system is the basis of chronic flooding in the area. Stovin et al., 2007, stated that the concept of SuDS retrofit offers an exciting and versatile yet currently underexploited opportunity for stormwater management in urban areas. Goh et al., 2017 worked on simulations for two study areas, Green Walk District and Tengah Subcatchment, under ABC Waters Singapore. Results showed a reduction in peak discharge $(22 \%$ to $63 \%)$ and a delay in peak discharge by up to $30 \mathrm{~min}$. Sustainable drainage solutions such as retention tanks, pervious pavements, green roofs, etc., can be implemented in public buildings and areas, to start with. Then larger private setups can be approached for the same. This will help reduce the load on the existing manmade system, which can be gradually phased out instead of upgrading the piped system.

Local authorities may enforce all new developments to have their stormwater drainage system with zero / minimum discharge into the public/ city drainage. This will reduce the burden on public infrastructure, and retention areas can be created. The collected water can be reused with minimum treatment arrangements. The green roof, a popular method in many countries to reduce runoff and heat island effect, can be made compulsory for these large and new developments. For example, as the Mithi River watershed was the most flood-affected area, public landuses, as shown in Figure 9, can be taken for green infrastructure implementation, especially the Bandra Kurla Complex. Yang et al., 2010 used correlation analysis on development conditions. The results show that an open drainage watershed generated less storm runoff than the conventional drainage watershed, given the similar impervious area in both watersheds. Furthermore, the open surface drainage watershed responded to rainfall in a way similar to its predevelopment natural forest conditions, indicating effective flood mitigation post-development.

Redesign the drainage system with modern methods and recreate the lost detention ponds, which will catch the runoff. Vincent et al., 2017 have carried out a cost-benefit analysis of SuDS with detention storage and have concluded that the use of storage and SuDS provides greater benefits with a larger reduction in flooding, and thus is more cost-effective than using SuDS alone. 


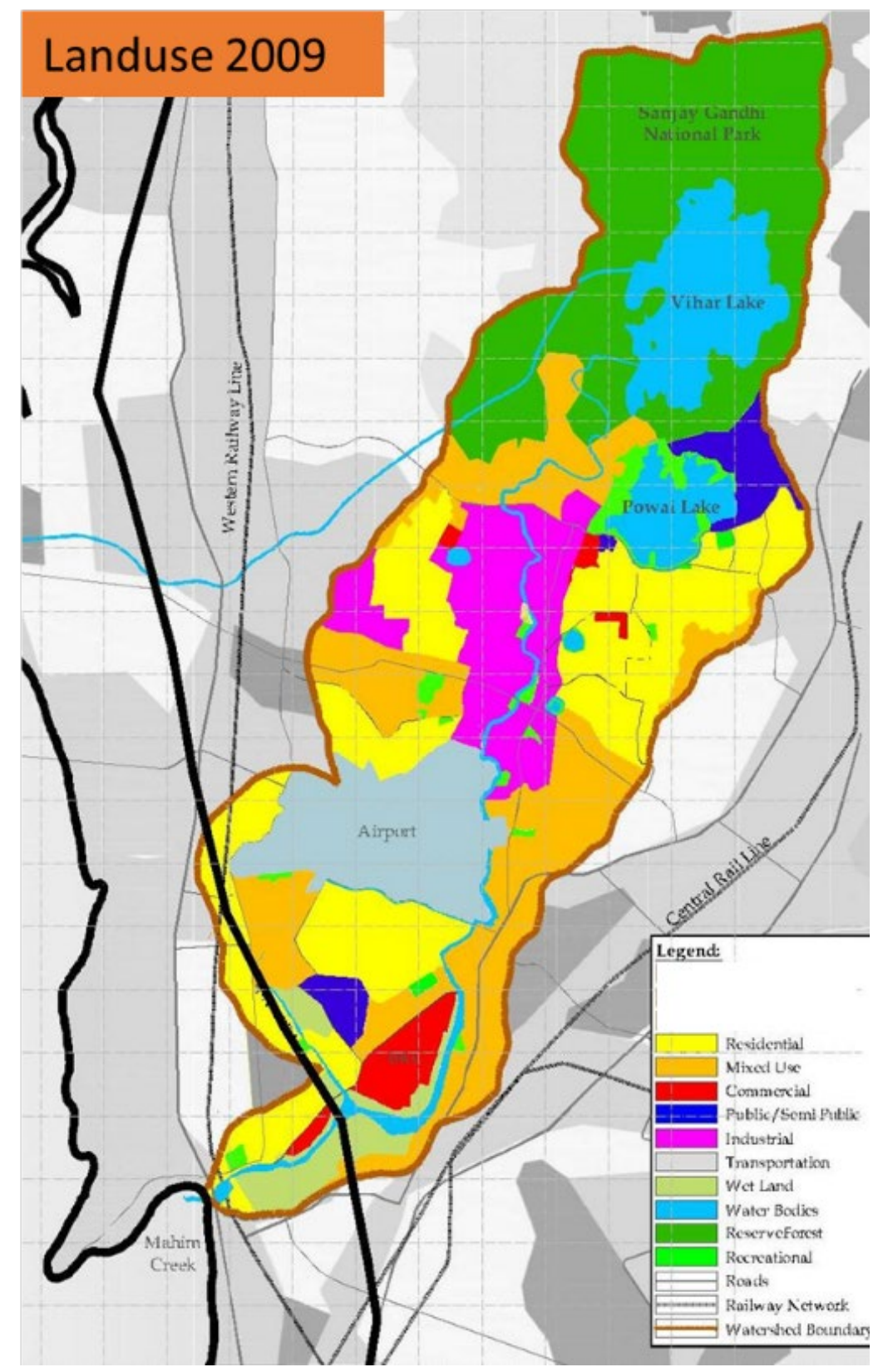

Figure 9. Landuse Plan 2009, Mithi River Basin, Mumbai

Source: Redrafted by Author 1 (as a part of studies carried out in School of Planning and Architecture, New Delhi, in 2009 - Original Source: Mumbai City Development Plan 2005-2025 and GoogleEarth 2021)

Also, the increased runoff coefficient and reduction in softscapes need to be compensated with creating / recreation of open spaces while reducing built footprint (through the redevelopment of certain areas), thus increasing percolation areas. This was demonstrated in Augustenborg, a highly populated neighborhood in Sweden, experienced floods caused by overflowing drainage systems. The resulting flooding led to damages, and untreated sewage entered watercourses due to increased pressure on the sewage treatment works. Green roofs, ditches, retention ponds, green spaces and wetlands were created. Thus rainwater run-off decreased by half. Additional benefits included improved water quality, reduced carbon 
emissions, aquifer recharge, and increased biodiversity. The increase in green space also improved the image of the area. (Davis et al., 2016). Retention ponds/ tanks can be constructed in public parks and all parking spaces can be made pervious.

Lastly, the issue of maintenance of water bodies and piped drainage needs to be taken up seriously by the local authorities. This may be tackled by creating public recreational spaces around the water bodies and conducting public awareness regarding the maintenance of these spaces. It may prove beneficial to encourage stakeholder participation in building and maintaining these recreational spaces. Zakaria et al., 2007 investigated the implementation of BIOECODS (similar to SuDS) in a campus. They concluded that it can be a variable method for water quantity and quality treatment for site runoff and biodiversity maintenance.

\section{CONCLUSION}

This paper discussed causative factors for increased flood events due to climate change, urbanization, inefficient and combined drainage system, and the severity of these frequent flood events. These factors were then discussed in detail, acting as interruptions in the natural and piped stormwater drainage system of Mumbai. The direct interruptions included land reclamation leading to low lying areas, developments on river basins hampering the flow of water bodies, design and capacity of the dilapidated piped drainage systems, and the sewerage system. The indirect interruptions identified included poor maintenance of drainage, reduction in mangrove areas previously acting as flood sponges for the city, and the increased runoff coefficient owing to uncontrolled urbanization. The paper tries to argue that it may be time for Mumbai to shift to sustainable solutions in terms of drainage management. These point towards the requirement of an integrated approach in tackling floods in Mumbai.

It has to be accepted that a focus on resilience building and designing indigenous solutions are needed for effective flood management in Mumbai. With a detailed study of the identified interruptions in the drainage system, suggestions have been made for sustainable solution options based on analysis and learnings from similar international success stories. SuDS may be capable of solving the flood problems in Mumbai and many other Indian cities. It may also prevent a lot of other cities from becoming chronic victims of flooding. It needs to be noted that even SuDS has its own set of constraints and challenges which need to be addressed before adopting it. The study carried out does not focus on climatic factors, governance issue, citizen's participation and acceptance of these new sustainable solutions, the scarcity of land in Mumbai city, the apprehension in shifting to a new format of infrastructure, and many more. Thus, it is recommended to create a localized version of SuDS that can cater to the climatic and subclimatic zones, its integration with other infrastructure, stakeholder acceptance, institutional arrangements for implementation, etc. India has realized the potential of SuDS through world scenarios but is yet to accept the modern solution. 


\section{REFERENCES}

Arunachalam B. (2005) Drainage Problems of Brihan Mumbai. Economic and Political Weekly, $40(36)$.

Bhattacharjee S. (2018) Storm Water Drainage in Mumbai. Mumbai Reader. Urban Design Research Institute, Mumbai, India.

Bobade M. N., Dolas S. D., Gadgul A. A., Gurme M. R. and Kote A. S. (2019) Sustainable Underground Water Drainage System for Mumbai City. International Journal of Engineering Research \& Technology (IJERT) 8 (6). ISSN online: 2278-0181

Bhagat R. B., Guha M. and Chattopadhyay A. (2006) Mumbai after 26/7 Deluge: Issues and Concerns in Urban Planning. Population and Environment, 27: 337-349. DOI: 10.1007/s11111-006-0028-z

Boogaard F.C. (2015) Stormwater characteristics and new testing methods for certain sustainable urban drainage systems in The Netherlands. Doctor of Philosophy, F.C.Boogaard, Delft University of Technology, Delft. ISBN 978-94-6259-745-7. DOI: https://doi.org/10.4233/uuid:d4cd80a8-41e2-49a5-8f41-f1efc1a0ef5d

Chan F.K.S., Griggiths J.A., Higgitte D., Xua S., Zhug F., Tanga Y., Xuh Y. and Thorne C.R. (2018) "Sponge City" in China-A breakthrough of planning and flood risk managemen $\mathrm{t}$ in the urban context. Land Use Policy, 76: 772-778. DOI: https://doi.org/10.1016/j.land usepol.2018.03.005.

Chatterjee P. Mopping up in Mumbai. World Report. (2005) THE LANCET, 366 (9488): 795. DOI: https://doi.org/10.1016/S0140-6736(05)67196-6

CIRIA (2015) The SUDS Manual; Dept. of Environment, Food and Rural Affairs, CIRIA: London, UK; ISBN 9780860177609.

Das, R. (2012) Sustainable Urban Drainage Systems - A possible solution to the problems of Flash Floods in New Delhi, India. -. CE5WEMb - Water and Environment Management, University of Birmingham. https://www.researchgate.net/publication/22832 7252

Davis M., Krüger I. and Hinzmann M. (2016) Coastal Protection and SuDS - Nature-Based Solutions, Policy Brief No. 4, November 2015.

Department of Urban Planning, School of Planning and Architecture, New Delhi. (2009) Managing Disaster Risks Mumbai Megacity 2009, Studio Project Report.

Dhankhar, V. (2017) Urban Flooding in India: Lessons Learnt and Roadmap for Future. Architecture Time Space and People, 17(11): 32-40.

Dhiman R., VishnuRadhan R., Eldho, T. I. and Inamdar A. (2019) Flood risk and adaptation in Indian coastal cities: recent scenarios. Applied Water Science, 9(5) DOI: https://doi.org/10.1007/s13201-018-0881-9

EDMAT (2019): OFDA/CRED International Disaster Database, Université catholique de Louvain - Brussels - Belgium.

Eckstein D., Künzel V., Schäfer L. and Winges M. (2019) Global Climate Risk Index 2020 Who Suffers Most from Extreme Weather Events? Weather-Related Loss Events in 2018 and 1999 to 2018. Germanwatch, www.germanwatch.org/en/cri; ISBN 978-3-943704-778 
Goh, P. X., Radhakrishnan, M., Zevenbergen, C. and Pathirana A. (2017) Effectiveness of Runoff Control Legislation and Active, Beautiful, Clean (ABC)Waters Design Features in Singapore. Water, 9(8): 627. DOI: 10.3390/w9080627

Government of India: Ministry of Housing and Urban Affairs. (2019) Manual on Storm Water Drainage System Volume-I Part A: Engineering Design, First Edition. Central Public Health and Environmental Engineering Organization (CPHEEO).

Government of Maharashtra. (2006) Fact Finding Committee on Mumbai Floods-Volume I and II.

Gupta K. (2007) Urban flood resilience planning and management and lessons for the future: a case study of Mumbai, India. Urban Water Journal, 4(3), 183 - 194.

Gupta K. (2009) Flood Disaster Mitigation and Management: A Synthesis and Key Lessons. Disaster \& Development: Journal of the National Institute of Disaster Management, 3(2) Special Issue: Urban Floods-II, 163-175

Indian Institute of Technology, Bombay (IIT-B). (2014) Report on Integrated Impact Assessment of Mithi River. Remote Sensing, GIS and Socio - Economic Studies of Mithi Catchment. Mumbai Metropolitan Region Development Authority(MMRDA). https://mmrda.maharashtra.gov.in/documents/10180/11271261/10/2bae8994-b9c2-4c209d9f-a6c3abebbc15?version $=1.0$

Jain A.K. (2006) The concept of bio-drainage in flood prevention and the avoidance of water scarcity. International Journal of Environmental Studies, 63(1): 39-48. ISSN 0020-7233 print: ISSN 1029-0400 online. DOI: 10.1080/00207230500410224

Jainer S. (2020) Urban flooding around the world: Where is India placed? DownToEarth. 26 April 2020. Accessed on 26 June 2020. https://www.downtoearth.org.in/blog/water/ur ban-flooding-around-the-world-where-is-india-placed--70765

Kadave P. T., Kale A. D. and Narwade S. (2016) Mumbai Floods, Reasons and Solutions. International Journal of Scientific and Research Publications, 6(3). ISSN 2250-3153

Kapur A. (2005) Disasters in India-Studies in grim reality. Rawat Publications. ISBN: 9788170339328

Khan M. (2014) Significance of Mangroves in Flood Protection of Coastal area: A Case Study of Mithi River, Mumbai, India. World Journal of Environmental Biosciences, 3(2): 97108. eISSN 2277- 8047

Kirtane G. (2011) Making the Sewer... A river again. Why Mumbai must reclaim its Mithi. Observer Research Foundation Mumbai. Report. https://www.indiawaterportal.org/sites/ default/files/iwp2/why_mumbai_must_reclaim_its_mithi_gautam_kirtane_orf_2011.pdf

Maharashtra Pollution Control Board, Mumbai. (2014) Comprehensive Study/ Profiling Of Mithi River. Report.

Mendiratta P. and Gedam S. (2018) Assessment of urban growth dynamics in Mumbai Metropolitan Region, India using object-based image analysis for medium-resolution data. Applied Geography, 98: 110-120. https://doi.org/10.1016/j.apgeog.2018.05.017

Mumbai City Development Plan 2005-2025. (2006) Municipal Corporation of Greater Mumbai. Report.

Mumbai Transformation Support Unit. (2015) Land Reclamation Report. 
National Disaster Management Guidelines: Management of Urban Flooding. A publication of the National Disaster Management Authority, Government of India 2010, ISBN: 978-9380440-09-5

Perales-Momparler S., Jefferies C., Perigüell- Ortega E., Peris-García P. P. and Muñoz-Bonet J.L. (2013) Inner-city SUDS retrofitted sites to promote sustainable stormwater management in the Mediterranean region of Valencia: AQUAVAL (Life+ EU Programme). Novatech, 2013 - 8th International Conference on planning and technologies for sustainable management of Water in the City, Jun 2013, Lyon, France. 〈hal-03303449〉

Rawoot S., Wescoat Jr. J. L., Noiva K., and Marks A. (2015) Product of research on "Enhancing Blue-Green Environmental and Social Performance in High Density Urban Environments" Mumbai Case Study. Massachusetts Institute of Technology. Sponsored by the Ramboll Foundation. https://www.readkong.com/page/mumbai-case-study-ramboll-6548661

Sieker F. and Sieker H. (2009) Reforms towards a paradigm shift and a new technology for storm water management. German Water Act 150: 796-802. https://www.researchgate.net/publication/292058986_Reforms_towards_a_paradigm_shi ft_and_a_new_technology_for_storm_water_management

Sörensen J., Persson A., Sternudd C., Aspegren H., Nilsson J., Nordström J., Jönsson K., Mottaghi M., Becker P., Pilesjö P., Larsson R., Berndtsson R. and Mobini S. (2016) ReThinking Urban Flood Management-Time for a Regime Shift. Water, 8(8): 332. DOI: $10.3390 / \mathrm{w} 8080332$

Samant, H.P. (1996) Geomorphic Analysis of the Mumbai Mumbra region and its application using GIS. A PhD Thesis, Indian Institute of Technology Bombay (IIT-B), Mumbai.

Stovin V. R. and Swan A. D. (2007) Retrofit SuDS - cost estimates and decision-support tools. Water Management 160(4): 207-214. DOI: 10.1680/wama, 2007.160.4.207

Stecko S. and Barber N. (2007) Exposing Vulnerabilities: Monsoon Floods in Mumbai, India. Case study prepared for the Global Report on Human Settlements. https://unhabitat.org/sites/default/files/2008/07/GRHS.2007.CaseStudy.Mumbai.pdf

Vincent, S. U.; Radhakrishnan, M.; Hayde, L. and Pathirana A. (2017) Enhancing the Economic Value of Large Investments in Sustainable Drainage Systems (SuDS) through Inclusion of Ecosystems Services Benefits. Water, 9(11): 841. DOI: 10.3390/w9110841

Yang, B. and Li, M.H. (2010) Ecological Engineering in a New Town Development: Drainage Design in the Woodlands, Texas. Ecological Engineering 2010. 36(12): 1639-1650. https://doi.org/10.1016/j.ecoleng.2010.07.002

Bombay High Court. (2019) The Conservation Action Trust And ... vs Union Of India And 3 Ors. WRIT PETITION (L) NO. 560 OF 2019. Report. https://indiankanoon.org/doc/ 137208673/?type=print; Accessed on 15th Jan 2021.

Zakaria N.A., Ghani A. AB., Auyb K.R. and Ramli R. (2007) Sustainable Urban Drainage System (SUDS). $2^{\text {nd }}$ International Conference on Managing Rivers in the $21^{\text {st }}$ Century: Solutions Towards Sustainable River Basins. Riverside Kuching, Sarawak, Malaysia. https://www.researchgate.net/publication/255682863_Sustainable_Urban_Drainage_Syst ems_SUDS

Zope P.E., Eldhao T.I. and Jothiprakash V. (2012) Effect of Urbanization on the Mithi River Basin in Mumbai: A Case Study. 2012 International SWAT Conference. Indian Institute of Technology, Delhi. https://swat.tamu.edu/media/57025/J1-4-Zope.pdf 
Zope P.E., Eldhao T.I. and Jothiprakash V. (2016) Development of Rainfall Intensity Duration Frequency Curves for Mumbai City, India. Journal of Water Resource and Protection, 8(7): 756-765. DOI: 10.4236/jwarp.2016.87061. 